\title{
HUBUNGAN PENGETAHUAN MAHASISWI DAN DUKUNGAN ORANG TUA DENGAN PERILAKU MAHASISWI UNTUK MELAKUKAN KEBERSIHAN ORGAN REPRODUKSI DI AKADEMI KEPERAWATAN HERMINA MANGGALA HUSADA TAHUN 2019
}

\author{
Ns.Junita Maratur Silitonga, M.Kep ${ }^{1}$, Ns.Ria Anugrahwati, M.Kep ${ }^{2}$ \\ 1. Akademi Keperawatan Manggala Husada, Jakarta 13930, Indonesia \\ 2. Akademi Keperawatan Manggala Husada, Jakarta 13930, Indonesia
}

Email: junitasilitonga1969@gmail.com

\begin{abstract}
ABSTRAK
Kesehatan reproduksi remaja tergantung dari pengetahuan remaja tentang cara melakukan perawatan organ reproduksi, peran serta orang tua dalam memberikan informasi tentang kebersihan organ reproduksi, penelitian ini bertujuan untuk hubungan pengetahuan remaja putri dan dukungan orang tua dengan perilaku mahasiswi untuk melakukan kebersihan organ reproduksi di Akademi Keperawatan Hermina Manggala Husada. Penelitian ini menggunakan desain penelitian deskriptif korelasi yaitu penelitian yang dilakukan untuk melihat hubungan antara variabel independen dan dependen. Penelitian ini menggunakan metode kuantitatif non eksperimen dengan pendekatan cross-sectional. Sampel dalam penelitian ini adalah mahasiswi tingkat satu yang berjumlah 67 orang. Pengumpulan data menggunakan kuesioner. Analisa data menggunakan uji chi-square. Data menunjukan responden yang pengetahuan baik yaitu sebanyak 47 responden $(70,1 \%)$, dukungan orang tua baik yaitu sebanyak 44 responden $(65,7 \%)$, dan perilaku remaja putri untuk melakukan kebersihan organ reproduksi baik sebanyak 49 responden $(73,1 \%)$ ). Hasil penelitian menunjukkan bahwa ada hubungan antara pengetahuan dengan perilaku remaja putri untuk melakukan kebersihan organ reproduksi ( $\mathrm{p}$ value $<\alpha$ ), artinya ada hubungan antara dukungan orang tua dengan perilaku remaja putri untuk melakukan kebersihan organ reproduksi. Diharapkan orang tua yang memiliki anak remaja putri dapat berperan aktif dalam memberikan informasi dan edukasi tentang cara menjaga kebersihan organ reproduksi.
\end{abstract}

\section{Kata Kunci : Pengetahuan, Dukungan Orang Tua, Perilaku Mahasiwi}

\section{ABSTRACT}

Adolescent reproductive health depends on adolescent knowledge about how to care for the reproductive organs, the participation of parents in providing information about cleanliness of the reproductive organs, this study aims to relate the knowledge of adolescent girls and support parents with student behavior to perform hygiene of reproductive organs at the Hermina Nursing Academy Manggala Husada. This study uses a descriptive correlation research design that is research conducted to see the relationship between the independent and dependent variables. This study uses a nonexperimental quantitative method with a cross-sectional approach. The sample in this study were 67 first-rate female students. Data collection using a questionnaire. Analysis of the data used chi-square test. The result showed that respondents who had good knowledge were 47 respondents (70.1\%), good parental support as many as 44 respondents (65.7\%), and the behavior of adolescent girls to clean the reproductive organs well was 49 respondents ( $73.1 \%)$ Indicating that there was a relationship between knowledge and the behavior of adolescent girls to clean the reproductive organs ( $p$ value $<\alpha$ ), means that there was the relationship between parental support and the behavior of adolescent girls to clean the reproductive organs. It is expected that parents who have teenage girls can play an active role in providing information and education on how to maintain the cleanliness of the reproductive organs

Keywords : Knowledge, Parental Support, Young Women Behavior 


\section{A. PENDAHULUAN}

Masa remaja adalah masa kritis dalam kehidupan anak-anak perempuan, masa transisi kanak-kanak ke tanggung jawab dewasa, sehingga remaja perlu mendapatkan perhatian khusus dalam menjaga kesehatan terutama kesehatan reproduksi dalam masa pubertas (Ali \& Mohamed, 2015). Kesehatan reproduksi remaja yaitu kondisi sehat yang menyangkut sistem reproduksi (fungsi, komponen, dan proses) yang dimiliki oleh remaja baik secara fisik, mental, emosional dan spiritual (BKKBN, 2012 dalam Winerungan, 2013). Vagina merupakan organ reproduksi wanita yang sangat rentan terhadap infeksi, dikarenakan batas antara uretra dengan anus sangat dekat, sehingga kuman penyakit seperti jamur, bakteri, parasit, maupun virus mudah masuk ke liang vagina (Winaris, 2010).

Angka kejadian infeksi saluran reproduksi (ISR) tertinggi di dunia adalah pada usia remaja $(35 \%-42 \%)$ dan dewasa $(27 \%$ 33\%). Prevalensi ISR pada remaja di dunia tahun 2006 yaitu : kandidiasis (25\%-50\%), vaginosis bekterial (20\%$40 \%)$, dan trikomoniasis (5\%-15\%). Negara-negara di Asia Tenggara, wanita Indonesia lebih rentan mengalami ISR yang dipicu iklim Indonesia yang panas dan lembab. Jumlah kasus ISR di Jawa Timur seperti candidiasis dan servisitis yang terjadi pada remaja putri sebanyak $86,5 \%$ ditemukan di Surabaya dan malang. Penyebab tertinggi dari kasus tersebut adalah jamur candida albican sebanyak $77 \%$ yang senang berkembang biak dengan kelembapan tinggi seperti pada saat mentruasi. Organ reproduksi yang lembab dan basah, maka keasaman akan meningkat yang memudahkan pertumbuhan jamur (Kasdu, 2008 dalam Zahara, 2014).

\section{Menurut World Health Organization} (WHO) pada tahun 2013 kejadian akibat infeksi alat reproduksi sekitar 4 juta pertahun, $75 \%$ ditemukan di negara berkembang dan $15 \%$ di negara maju. Tahun 2015 jumlah penderita baru sekitar 5 juta pertahun dan terdapat di negara berkembang $80 \%$ sedangkan di negara maju 25\%. Penyakit yang ditimbulkan dari kurangnya personal hygine menstruasi yaitu kanker rahim $77 \%$, ISK $68 \%$, gatal-gatal kulit vagina $45 \%$, keputihan $40 \%$, radang pada permukaan vagina $35 \%$ dan demam $15 \%$ (WHO, 2016)

Indonesia sendiri ada Beberapa penyakit ginekologi dan gangguan kesehatan reproduksi perempuan seperti kemandulan $20 \%$, keputihan 15\%, kanker rahim 35\%, kanker serviks 52\%, dan kandididasis 5\% (Depkes, 2015). Berdasarkan survei Demografi Kesehatan Indonesia (SDKI), pada tahun 2014 tingkat kejadian infeksi alat reproduksi mencapai 20/100.000 dari jumlah penduduk Indonesia sedangkan pada tahun 2016 terjadi peningkatan 
sekitar 60/100.000 terinfeksi alat reproduksi. Artinya, setiap tahun selama periode 2014-2016 terjadi peningkatan kejadian infeksi alat reproduksi yang di sebabkan kurangnya personal hygine (SDKI, 2016).

Pengetahuan remaja putri tentang kebersihan organ reproduksi sangat penting karena semakin tinggi tingkat pengetahuan remaja putri tentang kebersihan organ reproduksi pada genetalia, maka dapat mencegah terjadinya infeksi pada organ genitalia. Pengetahuan remaja putri yang kurang tentang kebersihan organ reproduksi, seperti perilaku yang buruk saat Buang Air Besar (BAB) atau Buang Air Kecil (BAK) membersihkannya dengan air yang tidak bersih dan salah arah saat membersihkannya, memakai pembersih sabun, pewangi atau pembilas secara berlebihan, memakai celana dalam yang ketat dan tidak menyerap keringat, jarang mengganti celana dalam, jarang mengganti pembalut, hal tersebut dapat menjadi pencetus keputihan yang disebabkan karena beberapa faktor antara lain infeksi, benda asing, tumor dan normal (Ratna, 2015).

Sikap yang kurang dalam merawat vulva hygiene saat menstruasi seperti malas mengganti pembalut dapat menyebabkan infeksi jamur dan bakteri ini terjadi saat menstruasi karena bakteri yang berkembang pada pembalut. Personal hygiene saat menstruasi dapat dilakukan dengan cara mengganti pembalut setiap 4 jam dalam sehari. Setelah mandi serta buang air, vagina dikeringkan dengan tisue atau handuk agar tidak lembab. Pemakaian jenis celana dalam yang baik terbuat dari bahan yang mudah menyerap keringat (Agustian, R \& Izzati, W, 2014). Menurut Aulia Tahun 2012 dalam Nanlessy, dkk Tahun 2013, penyebab keputihan yaitu kurangnya perawatan remaja puteri terhadap alat genetalia seperti mencuci vagina dengan air yang tergenang diember, memakai pembilas secara berlebihan, menggunakan celana yang tidak menyerap keringat, jarang mengganti celana dalam dan tidak sering mengganti pembalut.

Penyebab kurangnya menjaga kebersihan organ reproduksi dapat menyebabkan terjadinya infeksi salah satunya keputihan. Dukungan dalam menjaga kebersihan organ reproduksi remaja putri didapat juga dari keluarga. Keluarga memiliki peranan yang sangat besar pada tahap-tahap perkembangan remaja putri dalam menjaga kesehatan organ reproduksi. Menurut Undang - Undang Republik Indonesia No.20 tahun 2003 tentang sistem pendidikan nasional pasal 7 ayat 2 bahwa orang tua berkewajiban memberikan pendidikan dasar kepada anaknya. Pendidkan dasar yang dimaksud dalam pasal tersebut mengandung pengertian yaitu pendidikan dalam segala 
aspek kehidupan, termasuk pendidikan seks (Sari, 2015).

Keluarga merupakan pihak pertama yang bertanggung jawab memberikan informasi tentang kesehatan reproduksi bagi remaja. Keluarga, ibu merupakan faktor penting dalam sikap personal hygiene saat menstruasi (Sari, 2015). Ibu adalah sumber informasi pertama tentang menstruasi, sehingga terhindar dari pemahaman yang salah mengenai kebersihan menstruasi dan kesehatan reproduksi. Masyarakat menganggap kesehatan reproduksi masih tabu dibicarakan oleh remaja tersebut dapat membatasi komunikasi antara orangtua dan remaja tentang menstrual hygiene. Akibatnya, remaja kurang mengerti, kurang memahami dan kadang-kadang mengambil keputusan yang salah mengenai kesehatan reproduksi (Suryati, 2012).

Minimnya informasi dan kurangnya peran orang tua dalam pendidikan kesehatan reproduksi sering menjadi salah satu persoalan yang membuat remaja salah dalam memberikan keputusan (Rahmawati, 2014). Dalam penelitian yang dilakukan oleh Parvathy, dkk (2006) dalam Sari (2015), 41\% dari anak perempuan mendapat informasi tentang menstruasi dari ibunya, 22,4\% mendapat informasi dari saudara perempuan, $21 \%$ dari teman, 4,45 dari televisi, dan 3,3\% dari anak perempuan mendapat informasi dari buku. Penelitian di Amerika menyebutkan $85 \%$ dari remaja mengetahui informasi tentang menstruasi dari ibu mereka (Gustina. E dan Djannah, SN, Tahun 2015). Masih ditemukannya mahasiswi yang belum mengetahui cara menjaga kebersihan organ reproduksi yang baik dan masih kurangnya peran keluarga dalam memberikan informasi tentang cara menjaga kebersihan organ reproduksi menyebabkan penulis tertarik untuk melakukan penelitian mengenai hubungan pengetahuan mahasiswi dan dukungan orang tua dengan perilaku mahasiswi tingkat satu untuk melakukan kebersihan organ reproduksi di Akper Hermina Manggala Husada

\section{B. Metodologi Penelitian}

Jenis penelitian ini adalah penelitian kuantitatif dengan desain deskriptif analitik, pendekatan menggunakan cross sectional yang mempelajari dan menganalisis tentang hubungan pengetahuan mahasiswi dan dukungan orang tua dengan perilaku mahasiswi untuk melakukan kebersihan organ reproduksi pada genetalia di Akper Hermina Manggala Husada.

\section{Hasil dan Pembahasan}

\section{Hasil}




\section{a. Pengetahuan}

Tabel 5.1 Distribusi Frekuensi Pengetahuan Mahasiswi Tentang Kebersihan Organ Reproduksi di Akper Hermina Manggalla Husada tahm $2019(\mathrm{n}=67)$

\begin{tabular}{|c|c|c|c|}
\hline \multirow{2}{*}{ No } & \multirow{2}{*}{ Pengetahluan } & \multicolumn{2}{|r|}{ Jumlah } \\
\hline & & Freduensi & Persentase $(\%)$ \\
\hline 1. & Kurang & 20 & $29,9 \%$ \\
\hline Hasil & penelitian & tabel $5_{4} 1$ & berdasar,kan \\
\hline penge & ahivialah & mahasiswi & teifftang \\
\hline
\end{tabular}

kebersihan organ reproduksi di Akper

Hermina Manggala Husada tahun 2019

lebih didominasi oleh responden yang pengetahuan baik yaitu sebanyak 47 responden $70,1 \%$ ) sedangkan pengetahuan yang kurang baik ada sebanyak 20 responden $(29,9 \%)$.

b. Dukungan orang tua

Tabel 5.2 Distribus Frekuensi Dukungan Orang Tua Pada Mahasiswi Tentang Kebersihan Organ Reproduks di Akper Hermina Manggala Husda tahun 2019 ( $\mathrm{n}=6$ ?)

\begin{tabular}{|c|c|c|c|}
\hline \multirow{2}{*}{ No } & \multirow{2}{*}{ Dukungan orang tua } & \multicolumn{2}{|c|}{ Jumlah } \\
\hline & & Frekuensi & Persentase $(\%)$ \\
\hline 1. & Kurang & 23 & $34,3 \%$ \\
\hline 2. & Baik & 44 & $65.7 \%$ \\
\hline & Jumlah & 67 & $100 \%$ \\
\hline
\end{tabular}

Hasil penelitian tabel 5.2 berdasarkan dukungan orang tua pada mahasiswi untuk melakukan kebersihan organ reproduksi di Akper Hermina Manggala Husada lebih didominasi oleh responden yang dukungan orang tua baik yaitu sebanyak 44 responden $(65,7 \%)$ sedangkan dukungan orang tua yang kurang ada sebanyak 23 responden $(34,3 \%)$.

$\begin{array}{lll}\text { c. Perilaku Mahasiswi Untuk } \\ \text { Melakukan Kebersihan } & \text { Organ } \\ \text { Reproduksi } & & \end{array}$

Tabel 5.3 Distribusi Frekuensi Perilaku Mahasiswi Untuk Melakukan Kebersihan Organ Reproduksi di Akper Hermina Manggala Husada. tahun 2019 ( $\mathrm{n}=67$ )

\begin{tabular}{|c|c|c|c|}
\hline \multirow{2}{*}{$\mathrm{N}_{0}$} & \multirow{2}{*}{$\begin{array}{l}\text { Perilaku Mahasisswi } \\
\text { untuk melakukan } \\
\text { kebersihan organ } \\
\text { reproduksi }\end{array}$} & \multicolumn{2}{|c|}{ Jumlah } \\
\hline & & Frekuensi & Persentase (\%) \\
\hline & Kurang & 18 & $26,9 \%$ \\
\hline Hasil & nelitian tabel & $5.37 \mathrm{~b}$ & $\begin{array}{r}73.1 \% \\
\text { asarkan }\end{array}$ \\
\hline
\end{tabular}
kebersihan organ reproduksi di Akper Hermina Manggala Husada lebih didominasi oleh responden yang perilaku mahasiswi untuk melakukan kebersihan organ reproduksi baik yaitu sebanyak 49 responden $(73,1 \%)$ sedangkan perilaku mahasiswi untuk melakukan kebersihan organ reproduksi kurang ada sebanyak 18 responden $(36,9 \%)$.

d. Hubungan Pengetahuan Dengan Perilaku Mahasiswi Untuk Melakukan Kebersihan Organ Reproduksi

Tabel 5.4 Hubungan Pengetahuan dengan Perilaku Mahasiswi Untuk Melakukan Kebersihan Organ Reproduksi Di Akper Hermina Manggala Husada Tahun 2019 (n=67)

\begin{tabular}{|c|c|c|c|c|c|c|c|c|}
\hline \multirow{3}{*}{ Pengetahuan } & \multicolumn{4}{|c|}{ Perilaku Mahasiswi } & \multirow{2}{*}{\multicolumn{2}{|c|}{ Jumlah }} & \multirow{3}{*}{$\begin{array}{c}\text { OR } \\
(95 \% \mathrm{CI})\end{array}$} & \multirow{3}{*}{$\begin{array}{c}\mathrm{P} \\
\text { value }\end{array}$} \\
\hline & \multicolumn{2}{|c|}{ Kurang } & \multicolumn{2}{|c|}{ Baik } & & & & \\
\hline & $\mathrm{n}$ & $\%$ & $\mathrm{n}$ & $\%$ & $n$ & $\%$ & & \\
\hline \multirow{3}{*}{$\begin{array}{l}\text { Kurang } \\
\text { / Oktob } \\
\text { Baik }\end{array}$} & \multirow{3}{*}{\multicolumn{2}{|c|}{$\begin{array}{lc}11 & 55,0 \\
2 \mathrm{ar} & 2019 \\
7 & 14,9\end{array}$}} & 9 & 45,0 & 20 & 100 & \multirow{4}{*}{$\begin{array}{l}6,984 \\
2,120-26 \\
23,003\end{array}$} & \multirow[t]{4}{*}{0,002} \\
\hline & & & & & & & & \\
\hline & & & 40 & 85,1 & 47 & 100 & & \\
\hline Jumlah & 18 & 26,9 & 49 & 73,1 & 67 & 100 & & \\
\hline
\end{tabular}


Berdasarkan tabel 5.4 diatas terlihat bahwa hasil uji statistik pada variabel pengetahuan dengan perilaku mahasiswi untuk melakukan kebersihan organ reproduksi menggunakan uji chi-square. Uji tersebut memperoleh hasil 18 responden yang perilaku mahasiswi kurang kategori pengetahuan kurang sebanyak 11 responden $(55,0 \%)$ dan termasuk kategori pengetahuan baik sebanyak 7 responden $(14,9 \%)$, sedangkan dari 49 responden yang perilaku mahasiswi baik kategori pengetahuan kurang sebanyak 9 responden $(45,0 \%)$ dan termasuk kategori pengetahuan baik yaitu sebanyak 40 responden $(85,1 \%)$. Didapat nilai $\mathrm{p}$ value $=0,002$ lebih kecil dari $\alpha=0,05$, yang menunjukkan Hipotesis Alternatif $\left(\mathrm{H}_{\mathrm{a}}\right.$ diterima atau menunjukkan bahwa ada hubungan antara pengetahuan dengan perilaku mahasiswi untuk melakukan kebersihan organ reproduksi di Akper Hermina Manggala Husada Tahun 2019. Nilai OR 6,984 yang artinya responden yang kategori pengetahuan baik mempunyai kemungkinan 6 kali akan berprilaku baik untuk melakukan kebersihan organ reproduksi dibandingkan responden yang kategori pengetahuan kurang.

e. Hubungan Dukungan Orang Tua Dengan Perilaku Mahasiswi Untuk Melakukan Kebersihan Organ Reproduksi

Berdasarkan tabel 5.5 diatas terlihat bahwa hasil uji statistik pada variabel dukungan orang tua dengan perilaku mahasiswa untuk melakukan kebersihan organ reproduksi menggunakan uji chisquare. Uji tersebut memperoleh hasil 18 responden yang perilaku mahasiswi kurang kategori dukungan orang tua kurang sebanyak 12 responden $(52,2 \%)$ dan termasuk kategori dukungan orang tua baik sebanyak 6 responden $(13,6 \%)$, sedangkan dari 49 responden yang perilaku mahasiswi baik kategori dukungan orang tua kurang sebanyak 11 responden $(47,8 \%)$ dan termasuk kategori dukungan orang tua baik yaitu sebanyak 38 responden $(86,4 \%)$. Didapat nilai $\mathrm{p}$ value $=0,002$ lebih kecil dari $\alpha=0,05$, yang menunjukkan Hipotesis Alternatif $\left(\mathrm{H}_{\mathrm{a})}\right.$ diterima atau menunjukkan bahwa ada hubungan antara dukungan orang tua dengan perilaku mahasiswi untuk melakukan kebersihan organ reproduksi di Akper Hermina Manggala Husada Tahun 2019. Nilai OR 6,909 yang artinya responden yang kategori dukungan orang

Tabel 5.5 Hubungan Dukungan 0rang Tua dengan Perilaku Mahasiswi tua baik mempunyai kemungkinan 6 kali Untuk Melakukan Kebersihan Organ Reproduksi Di Akper Hermina Manggala Husada Tahun 2019 (n=67)

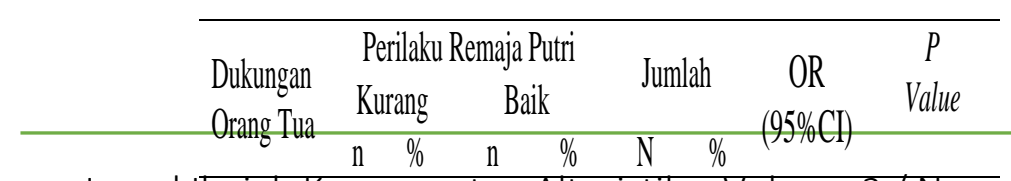
akan berprilaku baik untuk melakukan kebersihan organ reproduksi

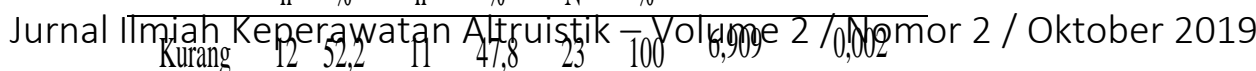


dibandingkan responden yang kategori dukungan orang tua kurang.

2. Pembahasan

a. Hubungan antara pengetahuan dengan perilaku mahasiswi untuk melakukan kebersihan organ reproduksi

Hasil uji statistik didapatkan nilai $\mathrm{p}$ value $=0,002$ lebih kecil dari $\alpha=$ 0,05, yang menunjukkan bahwa ada hubungan antara pengetahuan dengan perilaku mahasiswi untuk melakukan kebersihan organ reproduksi di Akper Hermina Manggala Husada.Hasil penelitian ini didukung oleh penelitian yang dilakukan oleh Yuliana (2010) pada remaja putri SMA Muhammadiyah 7 Yogyakarta, menunjukkan bahwa terdapat hubungan antara pengetahuan tentang menstruasi dengan perilaku hygiene menstruasi dengan nilai $\mathrm{p}=0,000$ $(\mathrm{p}<0,05)$.Hasil penelitian ini sejalan dengan penelitian yang dilakukan oleh Fathin , Syamsulhuda, dan Laksmono (2018) melakukan penelitian tentang faktor-faktor yang mempengaruhi perilaku vulva hygiene pada remaja putri panti asuhan di kecamatan tembalang, kota semarang, dari hasil penelitian didapatkan bahwa ada hubungan hubungan antara pengetahuan, status ekonomi, dan dukungan keluarga terhadap perilaku vulva hygiene pada remaja putri panti asuhan di kecamatan tembalang. Hasil penelitian ini senada dengan penelitian yang dilakukan oleh Lauren, Fransisca (2012) melakukan penelitian tentang hubungan pengetahuan remaja terhadap sikap remaja putri untuk melakukan vulva hygiene di Afrika menunjukkan bahwa ada hubungan antara pengetahuan remaja terhadap sikap remaja putri untuk melakukan vulva hygiene.

Menurut analisis peneliti pengetahuan dan perawatan yang baik merupakan faktor penentu dalam memelihara kesehatan reproduksi, hal ini dikarenakan organ genetalia merupakan salah satu organ tubuh wanita yang sensitif dan memerlukan perawatan khusus. Semakin tinggi pengetahuan mahasiswi tentang perawatan organ reproduksi maka semakin baik pula perilaku mahasiswi dalam melakukan vulva hygiene. Kemajuan IPTEK saat ini memudahkan remaja untuk mengakses informasi tentang cara perawatan vulva haygiene dan dampak jika tidak melakukan 
perawatan vulva hygiene dengan baik.

\section{b. Hubungan antara dukungan} orang tua dengan perilaku mahasiswi untuk melakukan

\section{kebersihan organ reproduksi}

Hasil uji statistik didapat nilai $\mathrm{p}$ value $=0,002$ lebih kecil dari $\alpha=$ 0,05 , yang menunjukkan Hipotesis Alternatif $\left(\mathrm{H}_{\mathrm{a}}\right)$ diterima atau menunjukkan bahwa ada hubungan antara dukungan orang tua dengan perilaku mahasiswi untuk melakukan kebersihan organ reproduksi di Akper Hermina Manggala Husada. Hasil penelitian ini senada dengan penelitian yang dilakukan oleh Dhingra (2009) menunjukkan bahwa adanya larangan sosial dan sikap negatif orang tua dalam membahas isu-isu terkait secara terbuka telah menghambat akses remaja untuk informasi yang tepat. Jika ibu mengkomunikasikan pandangan yang positif tentang menstruasi, maka remaja putri juga akan memiliki pandangan yang positif. Tetapi jika ibu memberikan pandangan yang negatif, remaja putri lebih mungkin untuk mempunyai pandangan yang sama tentang menstruasi. Penelitian ini didukung oleh penelitian Sari (2015) yang menyatakan bahwa
$41 \%$ dari anak perempuan mendapat informasi tentang menstruasi dari ibunya, 22,4\% mendapat informasi dari saudara perempuan, $21 \%$ dari teman, 4,45 dari televisi, dan 3,3\% dari anak perempuan mendapat informasi dari buku.Menurut analisis peneliti keluarga merupakan pihak pertama yang bertanggung jawab memberikan informasi tentang kesehatan reproduksi bagi remaja. Didalam keluarga, ibu merupakan faktor penting dalam memberikan informasi dalam pemenuhan kebutuhan personal hygiene saat menstruasi atau pada saat terjadinya keputihan. Minimnya informasi dan kurangnya peran orang tua dalam pendidikan kesehatan reproduksi sering menjadi salah satu persoalan yang membuat remaja salah dalam memberikan keputusan dan akan berdampak terjadinya infeksi pada alat genetalia remaja putri.

\section{Kesimpulan Dan Saran}

\section{Kesimpulan}

Sebagian besar responden dikategorikan berpengetahuan baik tentang kebersihan organ reproduksi yaitu sebesar $70,1 \%$ orang).Umumnya yang menjadi responden memiliki dukungan orang tua yang baik yaitu sebesar $65,7 \%$ (44 
orang).Dari hasil penelitian ditemukan perilaku mahasiswi untuk melakukan kebersihan organ reproduksi kategori baik yaitu sebesar $73,1 \%$ (49 orang). Ada hubungan antara pengetahuan dengan perilaku mahasiswi untuk melakukan kebersihan organ reproduksi di Akademi Keperawatan Hermina Manggala Husada Ada hubungan antara dukungan orang tua dengan perilaku mahasiswi untuk melakukan kebersihan organ reproduksi di Akademi Keperawatan Hermina Manggala Husada.

\section{Saran}

\section{a. Bagi Instansi Pendidikan}

Diharapkan hasil penelitian dapat dijadikan sumber pustaka dan wacana bagi pembaca yang berada di perpustakaan dalam menambah wawasan dan ilmu pengetahuan tentang perilaku mahasiswi untuk melakukan kebersihan organ reproduksi

\section{b. Bagi Mahasiswi}

Diharapkan mahasiswi dapat meningkatkan perilaku untuk melakukan kebersihan organ reproduksi terutama pada saat menstruasi dan keputihan agar terhindar dari penyakit infeksi pada genetalia.

c. Bagi Orang Tua
Diharapkan orang tua yang memiliki mahasiswi dapat berperan aktif dalam memberikan informasi dan edukasi tentang cara menjaga kebersihan organ reproduksi

\section{d. Bagi Penelitian Selanjutnya}

Diharapkan hasil penelitian dapat menjadi data dasar untuk dilakukan penelitian lebih lanjut menggunakan pendekatan kualitatif dengan teknik pengumpulan data menggunakan wawancara mendalam atau FGD.

\section{Ucapan Terima Kasih}

Peneliti mengucapkan terima kasih kepada mahasiswa yang telah berperan aktif dalam penelitian ini.

\section{DAFTAR PUSTAKA}

Arikunto, s. 2006 Dalam Latif (2015). Prosedur penelitian suatu pendekatan praktik. Jakarta: Rineka cipta

Arikunto. (2006). Teori \& Pengukuiran Pengetahuan, Sikap, dan Perilaku Manusia. Nuha Medika. Yogyakarta

Ayuningtyas,.(2011). Hubungan Antara Pengetahuan Dan Perilaku Menjaga Kebersihan Genitalia Eksterna Dengan Kejadian Keputihan Pada Siswi SMA Negeri 4 Semarang. Fakultas Kedokteran Universitas Diponegoro.

Ayuningsih. (2009). Psikologi perkembangan anak, Yogyakarta: Pustaka Larasati.

Ayu, (2010). Hubungan Pengetahuan dan Perilaku Vulva Hygiene terhadap Keputihan pada siswi SMA Negeri 
1 Jepara. Jepara, Akademi

Kebidanan Al-Hikmah Jepara.

Auli, Nanlessy, dkk.,( 2013). Hubungan antar

Pengetahuan dan Perilaku Remaja

Puteri dalam Menjaga Kebersihan

Alat Genitalia dengan Kejadian

Kepuithan di SMA Negeri 2

Pineleng. Ejournal Keperawatan,

Volume 1. : hal. 3. Volume 1.

Nomor 1.

Azwar, (2011). Sikap manusia teori dan pengukurannya. Edisi 2.

Yogyakarta:Pustaka Pelajar.

Azwar, S.(2012). Sikap Manusia teori dan Pengukurannya. Yogyakarta: Pustaka Pelajar.

Azwar.(2011). Metode Penelitian. Yogyakarta : Pustaka pelajar.

Basta, (2014). Perkembangan Sosial Remaja dalam Aspek Kemandirian. Jurnal Peesikologi Perkembangan

Baron dan Byrnes juga Myres dan Gerengun yang dikutip oleh Wawan, A dan Dewi, M. (2010). Teori dan Pengukuran Pengetahuan, Sikap dan Perilaku Manusia.. Yogyakarta : Nuha Medika

Basta, (2014). Peran Keluarga Batih dalam Pembetukkan Kepribadian dan Identitas Etnik. Jornal Pemberdayaan Comunitas.

Beccary. (2012). Prosedur Penelitian Suatu Pendekatan Praktik. EGC. Jakarta

Dharma, 2011). Manajemen Supervisi. Raja Grafindo Persada, Jakarta

Depkes RI, 2009. Sistem Kesehatan Nasional.

(Online). www.depkes.go.id

Depkes. (2016). Kesehatan Remaja Problem dan Solusinya. (Online).www.depkes.go.id

Dianawati, 2010 dalam Sari (2015). Mempersiapkan Masa Puber. Jakarta: Restu Agung.

Dianawati, 2010 dalam Sari. (2015). Pengaruh Penyuluhan Personal Hygiene Terhadap Tingkat Pengetahuan Mengenai Personal Hygiene Pada Kelas IV SDN Pampang. Kec. Panakukang kota Makasar. Diakses http://library.stikesnh.ac.id. Tanggal 13 november 2018.
Elmart. (2012). Cara Merawat dan Menjaga Kebersihan Vagina. Di Akses pada tanggal 30 november 2018. http://www.indonesiaindonesia.co $\mathrm{m} / \mathrm{f} / 23177$-cara-merawatvagina/.

Frisca, (2012). Hubungan Pengetahuan dan Perilaku Vulva Hygiene terhadap Keputihan pada siswi SMA Negeri 1 Jepara. Jepara, Akademi Kebidanan Al-Hikmah Jepara.

Fadlil (2011). Ilmu Kesehatan Masyarakat Prinsip-Prinsip Dasar.Jakarta: Rineka Cipta

Gustina. E dan Djannah, SN, Tahun 2015). Pengembangan Model Kesehatan Reproduksi Remaja. Buletin Penelitian Sistem Kesehatan Volume 8.

Gustina. E dan Djannah, SN, 2015). Sumber Infoermasi dan Pengetahuan tentang menstrual Hygiene pada Remaja Putri. Jurnal Kesehatan. Masyarakat.

Gustina. E dan Djannah, SN, (2015). Pengetahuan dan Persepsi Mengenai Hygiene Menstruasi pada Siswi SDN Jaka Setia III, Bekasi, Tesis, FKM UI, Depok.

Gustina. E dan Djannah, SN, (2015). Memahami Kesehatan Reproduksi pada Wanita. Edisi 2. EGC. Jakarta.

Handayani, (2011). Pengetahuan, Sikap dan Tindakan Remaja Puteri tentang Hygiene pada saat menstruasi. Skripsi FKM-USU

Hartup dalam Didi, (2012). Didi. Peranan Hubungan Teman Sebaya dalam Perkembangan Kompetensi Sosial Anak. (Online).http://dtarsidi.blogspot.com.

Hastono, P, (2008). Sutanto. Analisis Data Kesehatan. Depok: Fakultas Kesehatan Masyarakat

Hastono (2008). Analisis Data pada Bidang Kesehatan. Jakarta : Rajawali Press.

Hastono (2011). Pengolahan dan analisis data kesehatan. Yogyakarta. Numed.

Hastono P.S. (2007). Pengolahan data uji instrumen. Jakarta: UI Press

Kumalasari \& Adhyantoro.(2012). Hubungan antara Pengetahuan dan Sikap 
Siswi putri saat Mengalami Menstruasi di SMPN 3 Kecamatan Sawoo Kabupaten Ponorogo. Ponorogo. Jurnal Universitas Muhammadiyah Ponorogo.

(Online).www.umpo.ac.id

Kusmiran.( 2012). Kesehatan Reproduksi Remaja dan Wanita. Jakarta : Salemba Medika

Kusmiran. (2011). Perilaku Remaja Putri dalam Perawatan Kebersihan Alat Kelamin pada Saat Menstruasi di SMP Negeri 3 Pulau Rakyat Kabupaten Asahan Tahun 2010. Jurnal Universitas Muhammadiyah Ponorogo. (Online).www.umpo.ac.id

Laursen (2009). Hubungan Antara Dukungan Sosisal dari Teman Sebaya Dengan Problem Solving Pada Remaja. Jakarta : Fakultas Psikologis Universitas Guna Darma.

Madani. (2010). Kesehatan Reproduksi Wanita. Jakarta ; Arcan.

Mubarak, (2011). Promosi Kesehatan Sebuah Pengantar Proses Belajar Mangajar dalam Pendidikan. Yogyakarta: Graha Ilmu.

Mubarak, (2011).Hubungan Antara Pengetahuan Dan Sikap Tentang Gaya Hidup Sehat Dengan Perilaku Gaya Hidup Sehat Mahasiswa Di Psik Undip Semarang. Semarang:Jurnal Universitas Muhammadiyah Ponorogo.

(Online).www.umpo.ac.id

Mubarak (2007), Teori \& Pengukuiran Pengetahuan, Sikap, dan Perilaku Manusia. Nuha Medika. Yogyakarta

Mu'tadin,(2010). Kemandirian Sebagai Kebutuhan Psikologi Pada Remaja. Jakarta : www..E.Psikologi.co.id. (diakses tanggal 22 maret 2018)

Nurun \& Permatasari,(2010). Infeksi Saluran Reproduksi. (Online) http://www.ppl.depkes.go.id//IMS-
dan-ISR-pada-pelayanan-

kesehatanreproduksi/

Notoatmodjo, (2003). Metodelogi Penelitian Kesehatan. Jakarta ; Rineka Cipta

Notoatmodjo. (2003). Promosi Kesehatan dan Ilmu Perilaku. Jakarta : Rineka Cipta

Notoadmodjo S. (2010). Promosi kesehatan. Jakarta: Rineka Cipta.

Notoatmodjo (2010). Promosi Kesehatan dan Ilmu perilaku. Jakarta : EGC

Notoatmodjo, (2010). Pendidikan dan perilaku Kesehatan. Jakarta : PT. Rineka Cipta.

Notoatmodjo, (2010). Pengantar Pendidikan Kesehatan dan Ilmu Perilaku Kesehatan. Adi Offset. Yogyakarta.

Notoadmodjo (2010). Ilmu Kesehatan Masyarakat, Prinsip-prinsip Dasar. Jakarta: Rineka Cipta;

Nursalam. 2008. Konsep dan Penerapan Metodologi Penelitian Ilmu keperawatan. Jakarta: EGC

Nursalam, (2008). Pendekatan praktis metodologi Riset Keperawatan. Jakarta. Info Medika

Nursalam, (2013). Konsep Dan Penerapan Metodologi Penelitian Ilmu Keperawatan. Jakarta : Salemba Medika

Parvathy, dkk (2006). Hubungan Faktor Eksternal Dengan Perilaku Remaja Dalam Hal Kesehatan Reproduksi Di SLTPN Medan Tahun 2002. Jurnal Ilmiah Pannmed.

Pribakti. (2012). Kebutuhan dasar manusia dan proses keperawatan edisi 3. Salemba:Medika

Polit \& Back, (2008). Prosedur Penelitian Suatu Pendekatan Praktik. Jakarta: Rineka Cipta.

Proverawati. (2009). Menarche (Menstruasi Pertama Penuh Makna. Jakarta: Nuha Medika

Ratna. (2010). Kebutuhan Dasar Manusia Aplikasi Konsep dan Proses Perawatan. Jakarta : Salemba Medika.

Ratna.(2010). Pentingnya Menjaga Organ Kewanitaan. Jakarta: Indeks,

Rahmawati, (2014). Kesehatan Reproduksi Remaja. Jurnal Majalah Ilmiah 
Sultan Agung diterbitkan oleh Unissula.www.unissula.ac.id.

Rahmatika, D. (2010). Pengaruh Pengetahuan dan Sikap tentang Personal Hygiene Menstruasi terhadap Tindakan Personal Hygiene Remaja Putri Pada Saat Menstruasi di SMK Negeri 8 Medan Tahun 2010 Fakultas Kesehatan Masyarakat Universitas Sumatera Utara, Medan.

Rahmatika (2010). Kesehatan Reproduksi Remaja. Jurnal Majalah Ilmiah Sultan Agung, Universitas Sultan Agung.

(Online). www.unissula.ac.id

Rosid (2011). Kebudayaan dan Manusia Indonesia. Jakarta : LP3S

SDKI (2016), Kelangsungan pemakaian Kontrasepsi. Jakarta: Puslitbang KB dan Kesehatan Reproduksi, Badan Koordinasi Keluarga Berencana Nasional.

Santrock. (2010). Adolescence 7 th ed. Boston : Mc Graw-hill

Sari. (2015). Hubungan Pendidikan Seks Dalam Keluarga Dengan Perilaku Seksual Remaja Di SMAN 3 Bukittinggi Tahun 2012. Jurnal Kesehatan Masyarakat, Vol. 3 hal 27-31. Bukittinggi: STIkes Prima Nusantara. Diakses pada tanggal 13 April 2018.

Sari. (2015). Komunikasi Orangtua dan Perilaku Seksual Remaja Sekolah Menengah Kejuruan di Kota Baturaja. Jurnal Pembangunan Manusiawi, Vol. 4 No. 11. Diakses tanggal 13 Oktober 2018.

Sari (2015). Hubungan Tentang Menstruasi Terhadap Perubahan Perilaku Menstrual Hygiene Remaja Putri Untuk Pencegahan Infeksi Saluran Reproduksi. Jurnal Universitas Muhammadiyah Ponorogo.

(Online).www.umpo.ac.id

Sarwono. (2010). Psikologi Remaja. Jakarta : PT. Raja Grafindo Persada

Sevil,et al,. (2013). Hubungan antar Pengetahuan dan Perilaku Remaja Puteri dalam Menjaga
Kebersihan Alat Genitalia dengan Kejadian Kepuithan di SMA Negeri 2 Pineleng. Ejournal Keperawatan, Volume 1. : hal. 3. Volume 1. Nomor 1.

Setiadi (2013). Konsep Dan Proses Keperawatan Keluarga. Yogyakarta: Graha Ilmu

Suney, Kaya, dan Ergun,.(2011). Hubungan antara Pengetahuan dan Perilaku Menjaga Kebersihan Genitalia Eksterna dengan Kejadian Keputihan pada Siswi SMA Negeri 4 Semarang. Karya Tulis Ilmiah.

Sunaryo. 2004. Psikologi Untuk Keperawatan. Jakarta: EGC.

Suryati, (2012). Hubungan Tingkat Pengetahuan dengan Perilaku Pemeliharaan Kesehatan Organ Reproduksi pada Siswa Kelas VII SMP Negeri II Kasihan Bantul Yogyakarta Tahun 2010. Jurnal STIKES Alma Ata.(Online).www.stikesalma.ac.i d

Susanti (2015). Ilmu Keperawatan Komunitas Konsep dan aplikasi.Jakarta:Salemba Medika

Tabassum (2014), Hubungan Tingkat Pengetahuan, sikap, dan perilaku pemeliharaan organ reproduksi dengan resiko kejadian keputihan pada siswi kelas X SMA Negeri 1 Wonosari Kabupaten Klaten. Jurnal Universitas Muhammadiyah Ponorogo. (Online).www.umpo.ac.id

Wiknjosastro H. (2007). Anatomi Panggul dan Isinya. Jakarta: Yayasan Bina Pustaka Sarwono Prawirohardjo.

Wiwit. (2008). Faktor-Faktor yang Memengaruhi Kebersihan Organ Reproduksi Saat Menstruasi. Medan.

WHO, (2013). Program Kesehatan Remaja Putri. (Online).www.who.int 